Marquette University

e-Publications@Marquette

$1-1-2004$

Husserl's Theory of the Phenomenological Reduction: Between Life-World and Cartesianism

Sebastian Luft

Marquette University, sebastian.luft@marquette.edu

Accepted version. Research in Phenomenology, Vol. 34, No. 1 (2004): 198-234. DOI. (C) 2004 Brill Academic Publishers. Used with permission. 


\title{
Husserl's Theory of the Phenomenological Reduction: Between Life- World and Cartesianism
}

\author{
Author: Sebastian Luft
}

Abstract: This essay attempts a renewed, critical exposition of Husserl's theory of the phenomenological reduction, incorporating manuscript material that has been published since the defining essays of the first generation of Husserl research. The discussion focuses on points that remain especially crucial, i.e., the concept of the natural attitude, the ways into the reduction (and their systematics), and finally the question of the "meaning of the reduction." Indeed, in the reading attempted here, this final question leads to two, not necessarily related, focal points: a Cartesian and a Life-world tendency. It is my claim that in following these two paths, Husserl was consistent in pursuing two evident leads in his philosophical enterprise; however, he was at the same time unable to systematically unify these two strands. Thus, I am offering an interpretation which might be called a modified "departure from Cartesianism" reading that Landgrebe proposed in his famous essay from the 1950s, in which he was clearly influenced by Heidegger (a reading that is still valid in many contemporary expositions of Husserl's thought). This discussion should make apparent that Husserl's theory of the phenomenological reduction deserves a renewed look both in light of material that has since appeared in the Husserliana and in light of a new incorporation of the most important results of recent tendencies in Husserl research.

\section{Introduction}

Anybody attempting to give an account of Husserl's method of the phenomenological reduction finds him/herself in an ungratified position. After all, this theme has been one of the main topics in more than sixty years of Husserl research. ${ }^{1}$ Furthermore, this topic has been so dominant in Husserl's self-interpretation that talking about it equals discussing Husserl's phenomenology as a whole. A general account of what Husserl "really intended" with his phenomenology risks being superficial, because it can only conclude with generalities every traditional philosopher would claim as her or his telos: to express the truth about the world. Yet, were it true that "all great philosophers think the self-same," would either end up in trivialities regarding philosophical endeavors as such or we would miss Husserl's point as regards the uniqueness of his philosophical method. This notwithstanding that it was one of his late realizations that he could not simply do away with the tradition of which he himself was a part.

1 Luft 
While Husserl's self-characterizations, especially in his last work, The Crisis of European Sciences, seem to put off readers due to their ceremonious formulations, an approach "from the bottom up" will be more fruitful than a presentation from the perspective of his late position. At that time, he already was convinced of the deep veracity of his phenomenology and "certain of the future." Nevertheless, Husserl insisted that the reduction as the method to enter the sphere of phenomenology is not a device that, once performed, is valid for all times. It does not entail that the one who has been "converted"3 would remain so for the rest of one's life. Rather, the reduction must be practiced repeatedly; the greatest threat for the philosopher being to "fall out" of the mind-set of the philosophical attitude. This "danger" is integral to the performance of the reduction. If the reduction is the only way into transcendental phenomenology, then it must be part of this theory to furnish an entrance in a "didactic" fashion. As Husserl once puts it, nobody accidentally becomes a phenomenologist. ${ }^{4}$ Thus, making an entrance into phenomenology is a problem involving an enormous amount of philosophical effort comparable to that of Hegel's "Anstrengung des Begriffs" in determining the beginning of philosophy.

Yet, every philosophical theory is an answer to a problem, in response to which the theory receives its meaning, and this also goes for the phenomenological reduction. The first piece of theory leading to the reduction is the concept of epoché. This methodological device was intended, following the Skeptic tradition, to gain a view unbiased by the misguided theories of the past. Yet, the figure of bracketing is more than just terminologically derived from the Skeptics; rather, it comes out of a well-established philosophical background. To this, Husserl nolens volens contributes, even if he purports to completely do away with all previous philosophical problems by way of epoché to reach a "meta-physical neutrality." ${ }^{5}$ Thus, although his framing of the reduction only becomes understandable on the basis of his mature transcendental philosophy, the problem emerges from a philosophical context he did not create.

Thus, first I would like to expound the philosophical context, if only to show that Husserl distances himself from it. Husserl attempts to suspend traditional misconceptions in an effort to solve the fundamental philosophical problem of establishing "true and lasting knowledge." Nevertheless, he acknowledges the problem underlying his philosophical commencement, precisely that of the commencement itself. This problem is the "starting point" for his project and is equal to that of finding the true "entrance gate" to philosophy. This point of departure is already a problem of how to begin with philosophy. This presupposes that the act of philosophy is something "peculiar" compared to the "normal" execution of life. This issue, underpinning his 2 Luft 
philosophical enterprise, can be termed the epistemological problem. From here, Husserl progresses from a descriptive phenomenological psychology to a systematic universal "science" in a transcendental register. The problem of entering this emergent science is not a ladder to be thrown away once climbed. Rather, "the problem of entry" is, and remains, part of phenomenology itself.

In order to avoid lapsing back into an immanent reconstruction of Husserl's theory of the reduction, one must give a preliminary sketch of the epistemological problem that led Husserl to perform the transcendental reduction. The epistemological framing of the problem of introducing phenomenology will lead to an explication of the fundamental form of life, the "natural attitude." This is not only a problem of leaving this life form in order to make one's way into phenomenology. It is in itself a problem of thematizing this "primal" attitude, and in doing so, one is already performing the first step of the reduction. From there, I shall discuss the different ways into phenomenology. While the epoché deals with overcoming the natural attitude, the methodological problems of making a concrete way into the transcendental "realm" only begin here. One can discern three chief ways into phenomenology and show a certain systematics in their unfolding. This will be the issue of part two. In the third part, I will discuss the meaning the reduction had for Husserl. It has essentially two consequences that stand paradigmatically as the significance he attributes to transcendental phenomenology at large. However, I want to assert critically that in these two directions Husserl failed to show their systematic connection. Ultimately, we are left with two "loose ends" that Husserl was not able to tie together, perhaps because this is ultimately impossible.

Although the topic of the phenomenological reduction has oftentimes been an item of phenomenological research in the past—including the "defining" article by Kern ${ }^{6}$-one is now, some thirty years later, in a much better position to assess the meaning the reduction had for Husserl, especially in the light of manuscript material that has since appeared in the Husserliana. What I would like to attempt here is a renewed exposition of Husserl's theory of the reduction focusing on the concept of the natural attitude, the ways into the reduction, and finally, the upshot of the "meaning of the reduction" that leads to two, not necessarily related, focal points. While this discussion can-not be exhaustive, it should make apparent that the issue of Husserl's theory of the phenomenological reduction deserves a renewed look.

\section{I.The Epistemological Problem: The Relativity of Truths and the Overcoming of the Natural Attitude}

3 Luft 
The epistemological problem concerns, simply stated, true knowledge and the means of attaining it. This issue comes about where it is noticed as a problem. Hence, is knowledge eo ipso true knowledge? This depends not only on the meaning of knowledge but also on the context in which one employs it. The sciences represent one such field. The achievement and pursuit of true knowledge is vital to scientific practice and to the meaning of science. Whether one speaks of absolute truths (e.g., in mathematics or logic) or adequation to truth (e.g., in meteorology) the value of a science depends upon its reaching "true" knowledge.

The sciences, however, are not the only field in which knowledge is an issue. In opposition to them, there is prescientific life and the ordinary performance of life as carried out in the life-world. Whereas the problem of "absolutely true" knowledge seldom becomes a theme here, the question of truth is more crucial than one at first imagines. Consider, for example, the occurrence of a car accident. Imagine then the different "true stories" heard from different people involved: the drivers, a passer-by on the sidewalk, etc. Especially when some interest is at stake (who assumes the culpability), one will hear very (if not altogether) different "versions," all claiming "truth." These are "situational truths," and it is the task of a judge to "judge the truth," which might lie, as often implied, "in the middle." Obviously neither the notion of truth nor that of knowledge are taken emphatically (absolutely). The task of the judge entails the "distillation" of "the" truth from different stories. The result is only an approximation to what "really happened."Truth in this sense is an "idea." In the example, "truth" is an issue of rhetoric serving certain interests. There is no "absolute truth" about the car accident, although contradicting persons claim "true knowledge."

While here the justification for truths is debatable, there are other areas where we do talk of truth and true knowledge in an unemphatic manner. For example, in the market place one speaks of the "true" price of produce. The vendors fix the price anew each day depending on different circumstances (season). Hence, the daily price of a fruit is its situational "truth," and it is debatable: one bargains over the individual price every day. This notion of "truth" is relative to the situation. Nevertheless, it will have its "authority" and "rigidity" that is far from mathematical rigor. ${ }^{7}$ Knowledge of this truth is fashioned in a similar way. One calls the person experienced in employing these situational truths a good salesperson or a good bargainer, employing not "pure reason" but common sense. In a different context, Husserl mentions the example of the house to illustrate that a single object can yield differing "views" without invalidating others. What one perceives depends on who one is: A real estate agent views the house as an object for sale, an artist as a piece of art, etc. ${ }^{8}$ Within each perspective, these "interpretations" claim situational 4 Luft 
truths, although from an outside perspective, they are "mere" interpretations. None of these persons sees their views as an interpretation. ${ }^{9}$

Thus, in order for a situational truth to be a truth, it must block out other contradicting truths. The truth of the artist is different from that of the real estate agent but has its own "right," because both do not stand in competition with one another. But why not? The answer lies in the notion of interest. What "constitutes" a certain situation, what marks it as relative to other situations, is that the pursuit of a certain interest circumscribes a situation and "constitutes" a self-enclosed domain. The interest determines the truth of the situation. The interest of the real estate agent in selling the house determines his situational truth. The artist, likewise, pursues her own interest. Life in general is a "life of interest" ${ }^{" 10}$ containing a multiplicity of interests, each "creating" specific situations. However, one should not understand the situational "field" of an interest as exactly delineated. Rather, it has the character of a horizon that can expand and narrow, yet never comes to an end. There is no principal limit to that which can fall in the field of a certain interest. At the same time, these "fields" are selfenclosed due to the current interest in operation.

Situations are not islands in a sea. Rather, they are horizons extending over a partial stretch or field of being. As such, they are essentially limited (cf. Greek òpí̧દlu= to delimit) and exclude each other. The metaphor of tinted eyeglasses best illustrates this. Seeing through red glasses makes green objects invisible, whereas they will become visible when seen with glasses of another color. Similarly, a situational attitude blocks out other situations. Moreover, the image remains the same despite different colorings of the glasses. The object is in each case the same; it is "raw being" or "hyletic stock." In the natural attitude, however, we can never see this object in its purity, for this would involve stripping the world of its interest. Yet, due to its intentional character, life always implements a certain interest. There is no unintentional life, and intentionality always strives toward fulfillment. ${ }^{11}$

The world has thus a "face of interest" that it always shows us in one way or another. Since it is essentially a world of interests, one can give another notion to characterize the world: If the execution of life occurs in a multitude of situations, then life becomes the situation of all situations, or the horizon of all horizons. ${ }^{12}$ How is one to under-stand a "horizon of all horizons"? Husserl conceives of the life-world as the totality of life in its multitudinous facets. The life-world is the field in which life in general carries itself out in its everydayness. Whether Husserl calls this phenomenon life-world or "natural world-life," he alternately emphasizes either the noematic (the world) or the noetic (the subjective, living) aspect. The noetic-noematic structure designates 5 Luft 
the correlational a priori in its universal form. ${ }^{13}$ It signifies the essential relatedness of world and conscious life. The correlate to the life-world is that mode of living in which this life-world is the horizon for any kind of action: the "natural attitude."14

In order to enter the sphere of philosophy and to assume a philosophical point of view, one evidently has to relinquish the natural attitude. However, it is not entirely clear why this would be necessary, since as of now there is nothing "negative" involved in its characterization. Are there compelling reasons for "overcoming" natural life? What do 'natural' and 'philosophical' designate here? As it becomes clear in Husserl's further fleshing out of the natural attitude, he

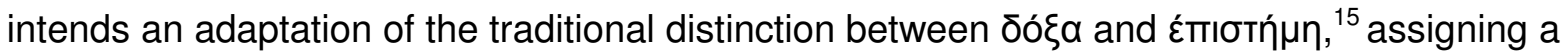
specifically "modern" interpretation to it that is localized on a higher level than that of "mere" prephilosophical naiveté and opposed to "mere" critical reasoning. ${ }^{16}$ Thus, when Husserl conceives of the 'natural' in opposition to the 'philosophical attitude', this echoes the distinction

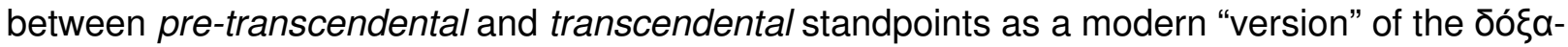

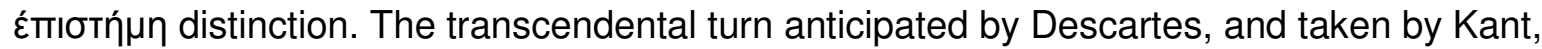
applies the realization of the subject-relativity of the world. The turn to the subject, the "reduction" to the ego (cogito), becomes the foundation of science. The world is not an "absolute being," but is relative to the experiencing subject. All experience is worldly, but world is always an experienced world. Thus, Husserl interprets Descartes' turn to the subject and Kant's transcendental philosophy as rudimentary forms of his transcendental turn. ${ }^{17}$ The realization of the essential subject-relatedness of all worldliness necessitates this transcendental turn.

To Husserl, this transcendental turn is identical with leaving the natural attitude, for the natural attitude knows per definition nothing of this correlational a priori. The distinction between "world" (as horizon of horizons) and nature ("stripped" of all apperceptions) illustrates the natural attitude's "naiveté." Because it knows nothing of this subject-relatedness, it lives in the belief it can perceive the world as nature -independent of any experiencing agent. However, this is impossible within the natural attitude as it would foster the illusion of seeing the world stripped of any interest. However, this is not to say that it is impossible to gain an "uninterested" view. To the contrary, the recognition that all situations in the natural attitude are guided by interests means stepping beyond the natural attitude. Yet, the elements that motivate this turn must already be present in the natural attitude. Thus, the epistemological problem that started this discussion consists, in other words, in being blind to the correlativity of world and experience.

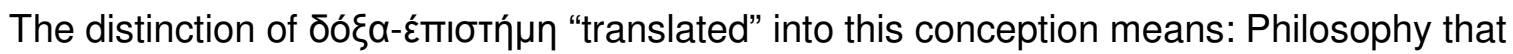
believes it can operate on a "realistic" level is bound to the natural attitude and it cannot be 6 Luft 
critical in the transcendental sense. This is not only Husserl's critique of pre-transcendental philosophy but especially of his pupils who neglected to pursue the transcendental path that he had taken up with Ideas I (1913).

This framing of the epistemological problem motivates the way into phenomenology, which is identical with becoming aware of the limits of the natural attitude. Phenomenology, for Husserl, is necessarily transcendental philosophy that entails adhering to the subjectrelatedness of all experience.

\section{II.The Performance of the Reduction: The Main Paths into the Reduction}

Husserl conceived several ways into the reduction, the number of which has been subject to debate. ${ }^{18}$ Of greater importance, however, is Husserl's belief in the systematic order of the reductions, regardless of the historic manner in which he discovered them. Within this systematics, none of these ways devaluates, but rather explicates and compliments, the others. Hence, this reconstruction attempts to adhere to the systematic order Husserl envisioned and disregards their temporal order of development. Legitimization of this disregard owes to Husserl's assertion that the Cartesian way retains its "right" and "validity" ${ }^{19}$ despite the problems Husserl sees with it. We will see, however, how these different ways lead to two "opposed" tendencies indicated in the title: to the "Cartesian" and the "life-world Husserl."

\section{A. The Cartesain Way}

If the reduction is not an impossible endeavor, then there must be certain "proto-forms" of putting the normal pursuit of life out of action within the natural attitude. Husserl considers a simple example of such a proto-form: the suspension of judgment two people will practice when in discordance with one another. If both are unsure of the truth of their judgments, they will suspend it, until they have found out thetruth. ${ }^{20}$ Only when one asserts the truth of the judgment hitherto uncertain, will it again be put into action. In the time between doubt and confirmation the judgment ("it is so") is "bracketed."

When Husserl labels this bracketing epoché, he takes it over from the Skeptic tradition. ${ }^{21}$ In a similar sense, Descartes' method in his Meditations is to be understood, according to Husserl, as an epoché insofar as the decision to "once in his life" overthrow all knowledge is equally a radical "step back" from everyday life. ${ }^{22}$ The question why the Cartesian epoché is the first way by which Husserl introduces the reduction is of great importance. When he later uses the term "reduction" for this method as a whole, he seems to identify both steps of epoché and reduction. This blurs certain nuances that one might want to retain for the sake of clarifying the 7 Luft 
details of this method. In addition, it is only from his later understanding of transcendental subjectivity that the concept of the reduction can become more dominant in the carrying out of this method. How does the epoché come about?

The natural attitude consists in viewing the world as "nature," as existing independent of an experiencing agent. This belief Husserl calls the general thesis of the natural attitude,${ }^{23}$ and it is a constant anonymous "stating as existing," for it is so fundamental that it is never actually uttered. It is comparable to a constant sound that the ear blocks out. In Husserl's words: "It is, after all, something that lasts continuously throughout the whole duration of the [natural] attitude, i.e., throughout natural waking life." ${ }^{24}$ Thus, the epoché, as putting the general thesis out of action, can be seen as making explicit this constant base line "below" the "natural" hearing level. The epoché does in no way devaluate or negate it, but rather puts it out of action momentarily in order to pay attention to that which remains unbracketed. In Ideas I, Husserl insists that this bracketing is a matter of our perfect freedom, i.e., the freedom to inhibit what we want to and to the extent we want to. ${ }^{25} \mathrm{He}$ later considered both elements ('how' and 'to what extent') of this "freedom" as problematic.

First, where does this freedom come from and how is it enabled? If the natural attitude is this self-enclosed field of everyday life, then why should, and how could, it be left by bracketing it? Secondly, even discussing the possible extent of the validity of the general thesis gives rise to an understanding of it as a field with a greater or smaller scope-ultimately like a continent within an ocean. Discussing a smaller or greater scope misconstrues the radicality of the epoché, which puts the general thesis out of action "with one stroke."

The general thesis of the natural attitude pervades every form of life, since all life is guided by a certain interest and hence (tacitly or explicitly) affirms being. ${ }^{26}$ Putting this life-pulse of continuous asserting out of action can only occur as totalizing act, and not piecemeal. There is either being in or out of action ("on" or "off"). However, whereas this radicality in fact calls for an equally radical motivation, this rigid "either-or" blurs the character of the "yes" of the general thesis and the possibility of "breaking its spell." It is a "yes" with respect to the character of the world as "existing," but this world is to be understood as existing in a manifold of ways, referring to the multitude of special worlds encountered in the natural attitude. How could it ever be possible to bracket all these modes of living with one single stroke? Apart from Husserl's insistence that it is a matter of our perfect freedom, a motivation for this step lies precisely in the relativities of the situational truths. If all of these are merely truths for themselves and if the philosopher's aim is to reach "absolute" truth, then it will seem plausible to refrain from asserting 8 Luft 
any of the former. This realization can already be seen as bracketing, since understanding these relativities as relativities overcomes being immersed in them. Situational truths can only consider themselves as truths if they take themselves to be absolutely true, where in fact they are only relative. The relativity is determined by not knowing about their situational characters; because they do not know this, they take themselves as "absolute." Not being bound to situations means already having left their realm. Indeed, leaving these situations behind and putting the validity of situational truths out of action are the same. Yet, understanding the relativities of situations as relativities —and having thus left the natural attitude — does not entail that one has consciously grasped the meaning of the epoché. To Husserl, it can only be fully achieved when one has reflected upon its meaning.

Hence, upon closer inspection, the metaphor of bracketing is yet more complex, involving two sides: that within the bracket and that without. Following the example of a doubtful judgment one does not consent to: the judgment will only be put back into action when one has "evidence" about its truth. Yet, the brackets can only be removed by an Ego that has evidence and asserts (or modifies) the old judgment. The method of bracketing necessarily reverts to the Ego, which is the executor of any act directed at the world. Thus, the "methodic expedient"27 Husserl takes over from Descartes—who carried out his method "for an entirely different purpose"28 - does not have the function of nullifying or negating the general thesis, but rather of motivating the turn to the subject that is the origin of the acts directed at the world. All situations are those of an Ego.

Thus, Husserl's main interest in the process of bracketing is to posit these brackets in order to determine what can be left "without." The universal doubt leaves over the doubting agent, a "pure" Ego stripped of any worldly meaning, and it is only this Ego that can claim for itself absolute evidence. What remains in spite of radical doubt is the transcendental Ego, which is not part of the world, but is that which "has" the world "opposed" to it as its universal correlate. This consciousness is the totality of the field of intentionality, as the correlate to the worldly totality given in intentional acts. As such, this subject cannot be a psychic entity in the world, but is consciousness "as such."Bracketing the totality of the world necessarily entails bracketing my ego as part of the world. What "remains" is not, as Husserl self-critically asserts in 1931, a "tagend of the world." ${ }^{29}$ Rather, the epoché reveals the pure ego, consciousness as such, opposed to the world; it reveals subjectivity as such which I as human being can access. ${ }^{30}$ Thus, of the motivations to practice the reduction, the strongest one arises in this Cartesian impetus of finding a basis from which to found apodictic evidence in the self-evidence of the ego. ${ }^{31}$ This 9 Luft 
search for an ultimate and final apodictic foundation, which, following the Cartesian paradigm, can only lie in the ego (cogito, ergo sum), is never given up by Husserl, no matter how much his actual emphasis might be directed at other "phenomena."32

However, it is not yet clear how one is to found a new scientific discipline from this basis "outside the world." In fact, is not this claim of a non-worldly subjectivity a metaphysical construction; does not this very step of reverting to an absolute ego lapse back into a Platonism? ${ }^{33}$ Although Husserl never gave up the claim of having laid the foundation of phenomenology on the basis of a Cartesian ego, it is difficult to see how a philosophical science could be "derived" from this absolute Ego, if one sticks, apart from a Cartesian method, also to his concept of subjectivity. Husserl's later self-interpretation intends to show that this way is merely one point of access among others and, furthermore, that a Cartesian notion of subjectivity as a "tag-end of the world" is unable to grasp subjectivity as a "field" of phenomenological intuition. Looking back upon Husserl's philosophical development after ldeas I, one can say that the Cartesian way remained dominant before he felt forced to broaden this approach, so as to stay "up to par" with the phenomenological conception of subjectivity he later attained. As we shall see, precisely his insights into the character of transcendental consciousness made it necessary to modify his way into the reduction. However, this modification was in no way an abandoning, but rather the extension, of this first way.

\section{B. The Psychological Way}

The Cartesian way was introduced with the intention of securing afield of apodictic evidence and, as such, to create a foundation on which apodictic knowledge could be built. Up until Cartesian Meditations(1931), Husserl employs Descartes' image of the tree of knowledge, whose branches are the positive sciences and whose trunk is the unifying scientia universalis. ${ }^{34}$ Phenomenology purports to be this unifying science; in this sense "Cartesianism" means that only evidence of "egoic" experience can give the ego apodictic evidence, whereas experience of worldly entities is potentially doubtful, deceiving, etc. This is so, essentially, because mundane experience can undergo modalizations. In Ideas I, Husserl considered the epoché as a turn away from the world and its experience to the realm of pure consciousness by virtue of bracketing the "reality claims" of the natural attitude, thus as a move from transcendence to pure immanence. ${ }^{35}$

The argument for this turn to "inwardness" as a basis for apodictic knowledge runs as follows. Nobody doubts the evidence of something given directly, in intuition. An external thing, a sensuous object, gives itself as itself, and is to be taken as such. The principle of all

10 Luft 
principles - to "take everything that gives itself in intuition originarily...as what it gives itself, but only within the boundaries in which it givesitself" ${ }^{\prime 36}$-is stated precisely to support this claim. However, upon closer inspection, what is seen of a perceptual object is merely its front side facing me. The back side will always be hidden; as I turn the object around to see its back side, its front side will again be hidden, etc. An external object always is given in "adumbrations," and therefore the evidence of this object will never be absolute. Indeed, the manifest side gives itself with apodictic evidence; in direct perception there can be no doubt about it. However, other unseen sides can always turn out to be different than anticipated. I will never see the totality of an external thing, the evidence regarding it will always be presumptive. Evidence about transcendent objects will not be apodictic. Since Husserl is searching for an absolute, apodictic foundation, the external experience of transcendent objects does not qualify. Immanent experience on the other hand does not adumbrate itself. It is given apodictically and adequately-or, there is no difference between both forms of evidence. Only inner experience can be the basis for apodictic knowledge, since there is no uncertainty regarding its evidence. "A mental process is not adumbrated....Rather is it evident...from the essence of cogitationes, from the essence of mental processes of any kind, that they exclude anything like that [sc., adumbrations]."37

To be sure, there is no backside to the anger I feel or reflection I carry out. If inner experiences do not adumbrate themselves, this means that they cannot have a "spatial" extension; the category of "spatiality" does not apply. It might be a form of intuition, but that which is intuited in inner experience is not spatial. While I can only imagine the external object as seeing it from its front side with its back side unseen, the imagination itself is given directly and absolutely. In other words, the lack of spatiality regarding inner experiences seems to be the criterion for not adumbrating. Whereas adumbrations are linked to spatiality, it will sound trivial to say that experience takes place in time. Following Husserl's analyses of time consciousness one can say that the time "of" these experiences is not external, natural time, but the time "of" the experiences themselves. Experiences are "given" in a temporal now in a "primal impression" within a constant flow of time consciousness. Experiences "flow away" from my current, living now and are retained within a certain halo from my present Now, until they recede out of the periphery of my "mental eyesight" into the "stock" of my memory. "Periphery" connotes a certain spatiality, namely, a distance from my present Now. This distance becomes apparent when an experience slips out of my immediate retention into memory, when I forget what I had just heard or thought. The very "act" of forgetting questions the apodictic evidence of 11 Luft 
inner experience. Nevertheless, one need not revert to such an obvious example. Already the "fading out" of experience in retention challenges the claim of apodicticity in inner experience in its totality. Inner experience can even deceive me; memory might be false or incomplete, etc. Having full and total access to all fields of my consciousness would mean that the Ego disposes over a divine consciousness.

Indeed, time can be seen as a certain analogue of space in the sense that, just as the spatiality of an object prevents us from gaining a fully transparent view of it, so does the temporality of lived-experiences keep us from "having" the totality of consciousness in one act. Since all actual experience is "had" in the lived present, the temporally extended nature of our mental life evades a complete overview. ${ }^{38}$ Because I can only view my mental life in a reflective gaze, I cannot "step outside" of it, since I am bound to the now in which my experiences are "actual." I will always have experiences, also of reflection, in a living present, and this present will move to an ever-new present from which previous experiences will recede into recollection. Thus, Husserl's own concept of time-consciousness "behind his back" counters his own claim to apodictic evidence of inner experience. Accounting for this in actual analyses subtly moves Husserl away from the Cartesian motif of apodictic evidence on the basis of ego cogito; for, were one to limit oneself to "egoic" experience in apodictic evidence, one would have to content oneself with in fact a very small portion of subjective life.

If one, however, leaves aside the claim to apodictic foundation, a whole world of subjective life opens up, readily available to be explored."This seemingly empoverished ego cogito has opened up to us an endless realm of instrinsically intertwined phenomena, so to speak a phenomenological jungle....[O]nly as a transcendental ego he [sc., the beginning philosopher] could posit himself and only his absolute life with cogito and cogitatum remains. However, it seems, an eternal manifold lies herein."39 Put otherwise, Husserl's insight into the extension of this cogito forces him to expand the sphere of the ego itself. At the same time, one cannot do without the ego, for there must be a synthesizing agent which binds the cogitationes together within one stream of consciousness. As Husserl says in the Cartesian Meditations, the form of ego-cogito-cogitatum is the general form of all conscious life. ${ }^{40}$ Including the cogitatum as the actual field of experience for the phenomenologist, apart from "foundationalist" intentions, gives rise to a whole new sphere of experience, which will be dealt with an equally novel discipline: phenomenological psychology. The questions, then, will be a) how to characterize this "field" of cogitate and, more importantly, b) how to account for it methodologically. Given the desideratum of such a new "transcendental science," Husserl has

12 Luft 
to give answers to two interrelated questions: what kind of analysis can there be of this phenomenal "realm" or "field," and how is this possible as a science, if this field structure in its breadth escapes the claim for apodictic evidence? What is the theme of phenomenological research, given that the ego is more than a pure ego? In a different terminology, how can one account for consciousness if consciousness itself has a "horizonal" structure?

From its inception in the Logical Investigations, phenomenology endeavors to analyze consciousness. The "positive" discipline for this is, naturally, psychology. However, phenomenology as rigorous science aims at moving from facts regarding the human consciousness to essences; it is an eidetic science of consciousness, as essentially characterized by the structure of intentionality. Yet, this intentionality is itself not a homogenous and "uniform" framework but is structured by the structure of cogito-cogitatum. Accounting for this "rich" structure calls for a whole "psychology" on the basis of the phenomenological principles (intentionality). Phenomenological psychology is this designated discipline performed on the basis of an eidetic description of conscious phenomena. Structuring this discipline has its own problems and difficulties, which shall not be discussed here. Yet it is clear how it would be necessary to systematically carry this out as a "universal" analysis. Husserl reflected intensely on how to perform this task in a systematic fashion. ${ }^{41}$ In short, he proceeds from a positive science within the whole of the human sciences. In this framework, psychology, as science of consciousness conceived as a single ego would be followed by the science of communal spirit ${ }^{42}$ in the framework of a phenomenology of intersubjectivity. However, these considerations, according to Husserl, thematize subjectivity as part of the world and hence remain bound to the natural attitude.

Hence, psychology is at first the thematization of an eidetics of (worldly) consciousness, but not transcendental subjectivity, because psychology as a positive science, due to its methodological naivety, remains blind to the transcendental dimension. ${ }^{43}$ Thus, in numerous attempts, Husserl strives to show how phenomenological psychology can motivate the reduction from worldly to transcendental consciousness by pointing out its methodological shortcomings and by explaining why a pheno-menological psychology must necessarily lead to the transcendental dimension. It might well be that the picture Husserl draws of such a pretranscendental psychology is a mere caricature in order to expound his own "transcendental discipline" in contrast to it; yet Husserl was also influenced by contemporary theories of psychology, which he hoped to embed in a transcendental framework. How, then, is the shift from phenomenological psychology to transcendental phenomenology motivated, and more 13 Luft 
importantly, how is it possible? Both questions belong together, for Husserl's strategy for demonstrating the necessity of moving to the transcendental dimension is to uncover the problems and paradoxes that arise if one remains bound to a purely "psychological" concept of subjectivity. Thus, how can I gain an overview over subjective life if I remain bound to my experience in the "lived present"?

The answer lies in the doctrine of the splitting of the ego, which addresses the problem arising from expanding the ego to a field structure. If consciousness is more than an Ego (a cogito)but a whole sphere of conscious life, then the question of the agent, the "unparticipating observer" ${ }^{44}$ carrying out this discipline, becomes pressing. An overview of this sphere-which is a sphere of intersubjectivity —harbors the danger of dissolving this very agent that strives to gain an uninhibited view over transcendental life. The life the ego experiences by reflection is nothing but the life of this agent itself-but is it entirely her life only? Yet, the Ego can only access this conscious life that it calls its own by introspection. Thus, reflecting on one's conscious life yields access to this consciousness, but it also creates the following problem: how can I have access to this conscious life as such if I can never step outside of my individual self? And even if I could gain access, how can I experience these regions, which are not mine alone, without losing my individuality? I can inhibit the general thesis of the natural attitude and turn to my consciousness. But how am I to characterize the relationship between myself, the observing agent, and that which I observe, if the latter is the whole sphere of consciousness? Would this not end up in a vicious circle?

In phenomenological psychology, as in any science, there is a region to be observed and an observer. Only here we face the curious situation that the observer and observed are of one and the same essence. Hence, only an artificial rupture, which splits the ego into an observer and a thematic field, can establish this difference of the same: the Ego and her own conscious life. "In my living present I have in coexistence the doubled ego and the doubled ego act; thus the ego, which now continuously observes [e.g.] the house, and the ego, which carries out this act: 'I am aware that I am continuously observing thehouse'."45 In principle this doubling has no limit. I can always again reflect upon that which I have just observed and reflect upon this reflection in infinitum. I can always make the part of the Ego that I reflect upon "patent," whereas the reflective ego will remain "latent."However, the reflection by a latent ego (which can occur repeatedly in "iteration") will render the latent ego patent, etc.46This infinite regress, to Husserl, is "undangerous" because we are not dealing herewith a logical foundation; rather, it reveals, over and over, the reflective "I can." Although the reflection upon yet another ego yields 14 Luft 
no new insight, the possible "iteration" of reflection proves the feasibility of the reflective faculty of consciousness and asserts the Ego's "insolubility" and centered "stability" in ever new reflective acts.

Whereas this iteration adds no new insight into the nature of consciousness, the splitting into the observer of conscious life and consciousness itself as a result of this activity can only occur as a radical split, a rupture within the originally unitary conscious life. "Naive" life has its breaks and ruptures, but is overall "one" due to the shared belief in the general thesis of the natural attitude. Hence, the break with the natural attitude in the epoché is to be conceived as a split between the philosophizing Ego and that which it observes, consciousness itself, in acting out its life intentionally in the form of the natural attitude. The epoché is hence a radical splitting of the Ego. The reflective ego is no longer under the "spell" of the general thesis; it reflectively turns its attention to consciousness, which, in turn, is intentionally directed at the world. As all intentional life "shoots at" the world and is as such "enamored" with it—here Husserl plays on the pun "verschossen" 47 -this reflective turn requires a radical change of attitude, although the intentional character of the reflective ego itself is not altered. An alter-native formulation of 'being intentionally directed at the world' is 'being interested in its affairs'. Hence, the term "uninterested observer" becomes understandable as not being interested in the general thesis of naively positing the world as existing in different ways. Husserl later prefers the term "unparticipating" to describe the "status" of this agent, as the term "uninterested" implies an indifference. To be sure, the observer is eminently interested in knowledge about consciousness—she is interested in a way the natural ego cannot and never will be "interested" as long as it lives in the natural attitude. Alternatively, and more adequately, "unparticipating" suggests that the philosophizing Ego does not participate in asserting the general thesis of the natural attitude.

This splitting enables a view on the totality of conscious life. This is not a "view from nowhere" because that which I gain access to is nothing but my own life from the first person perspective. What can this tell us about the discipline of phenomenological psychology, as yielding a point of access to phenomenology? Is it necessary for it to be a transcendental discipline? Ultimately, it has to be, because this totality only comes into view after a break with the natural attitude. The splitting of the ego and the break with the natural attitude are inextricably bound together. However, it is possible to practice an eidetic science of consciousness. Here, too, there is the difference between a scientific agent and the region this science thematizes. But this does not suffice to gain a total overview over consciousness as 15 Luft 
such. Thus, the consequence of the endeavor to thematize the totality of psychology's subject matter necessitates the transcendental turn, something that psychology by definition cannot accomplish. Thus, as long as this discipline does not inhibit the general thesis, it remains on the ground of the natural attitude as a positive science. Hence, paradoxically, mundane consciousness thematizes itself as part of the world. In the hierarchy of the foundational strata of nature and spirit this discipline deals with conscious life on the foundation of nature. The "personalistic" attitude, which psychology occupies and which is necessary to access subjectivity, is thus an abstraction from the natural attitude, which experiences the whole of constituted life, albeit without any knowledge of its own accomplishments of constituting the world for itself.

By contrast, transcendental subjectivity is not part of the world; it is the world's correlate as product of its constitution. Transcendental subjectivity is not in the world; it constitutes the world. Only the split-ting of the ego makes it possible for the observer to have a "transcendental experience" while remaining a mundane Ego. The Ego is at the same time an object in the world and a subject for the world. ${ }^{48}$ Yet, a phenomenological psychology, based in the natural attitude, is indeed possible. The transcendental viewpoint, already accessed in the Cartesian way, clarifies that this discipline, as a positive science, remains incomplete and methodologically ambiguous. A true phenomenological psychology is necessarily forced to perform the reduction and move from a mundane to a transcendental account. Thus, despite psychology's philosophical inadequacy, phenomenological psychology and transcendental phenomenology are "parallel" disciplines. This parallelism, however, vanishes with the realization that this consciousness is nothing but transcendental consciousness once one has inhibited the general thesis. Or, viewed from the transcendental "side," mundane consciousness is an incomplete "part" or "layer" of consciousness that is not part of the world, but correlated to it (the "correlational a priori”). Hence, a methodological consideration of phenomenological psychology reveals "that the consistent and pure execution of this task of a radical reform of psychology had to lead, of itself and of necessity, to a science of transcendental subjectivity and thus to its transformation into a universal transcendental philosophy."49

Apart from psychology's yielding an entrance gate to transcendental phenomenology or conceiving of psychology as a preliminary discipline before a treatment of 'consciousness as such', another result comes to the fore in expanding phenomenology into a full-blown transcendental discipline, namely, the unparticipating observer. Contrasted with the Cartesian approach, the establishing of this agent "saves" the philosophizing Ego from becoming "lost" or 16 Luft 
"drowning" within the vast transcendental field. Moreover, only this way of access to the transcendental as a sphere of experience opens the view towards transcendental intersubjectivity-as a community of subjects constituting a communal world. Yet, establishing this observer in a conscious methodological move retains the radicality of the Cartesian approach as it insists on a philosophizing agent practicing this introspection; it can be seen as a Cartesian remnant in a wholly different agenda. Only with the clear carving out of such an agent can the philosopher claim to take over responsibility for his or her own actions as a scientist and human being. Not by accident is Socrates the archetype of a radical inquirer, who has discovered the foundation of all knowledge in himself. ${ }^{50}$ For Husserl, practicing radical selfintrospection in the way outlined equates living the ethical ideal of self-responsibility. This explicit establishing of the philosophical observer thus opens the path to "ethical" considerations of the role of the philosopher, which are a crucial part of Husserl's late reflections. ${ }^{51}$

Thus, moving from the Cartesian approach to the way into phenomenology via psychology enables Husserl to harmonize the two requirements that satisfy his demand for rigorous science. The first task is that of founding a scientific discipline, which phenomenology claims to be-hence it provides more than "just" a philosophical foundation in an Ego, rather a discipline of the cogitate of this cogito in the broadest conceivable sense. The second requirement is that of living up to the "epistemologico-ethical" ideal of fully legitimizing the actions of the philosopher. This is only possible because the epoché opens up an overview over the totality of consciousness that hitherto, and by necessity, was hidden in this totality. As such, this science presents an ideal for all other sciences. The idea of science as well as that of the scientist are products of a variation from the philosopher as the "model scientist," and hence apply to all factual appearances of them. ${ }^{52}$

Thus, the way via psychology becomes the "grand path" into phenomenology, since such a psychology leads necessarily into transcendental phenomenology, if taken to its methodological conclusions. Psychology is the "field of decision" for an adequate framing of transcendental phenomenology. Put differently, the modern separation of psychology and transcendental philosophy has led to the fateful development in modern philosophy, psychologism. Husserl's transcendental phenomenology can be seen as an effort to combine both strands gone astray into one transcendental discipline. If psychology is truly to be part of critical philosophy, it cannot be carried out from "an empirical point of view" (as Husserl's heritage from the Brentano school made him believe), but rather "according to critical method," as, for example, Natorp the Kantian conceived of psychology. ${ }^{53}$

\section{Luft}




\section{The Way via the Life-World}

In his last attempt to present an introduction into phenomenology in the Crisis, Husserl proposes yet another way, that via the life-world(the "ontological way"). ${ }^{54}$ Although he already pursued this path in his earlier work from the 1920s, it is not until the Crisis that it achieves its most mature presentation as Husserl's "last word" regarding this topic. Without devaluating his previous attempts, Husserl considered this path the principal one, although Husserl merely draws the consequence from his earlier reflections. What motivated Husserl to broach yet another path and what are its main lines of thought?

Insight into the nature of transcendental consciousness reveals "the transcendental" to have essentially intersubjective and genetic dimensions. On the deepest level (passivity) it cannot even be called "subjective" anymore. Husserl uses different terms to describe it, from simply "the transcendental" to "transcendental world," etc. The initial conception of transcendental subjectivity is expanded into two major dimensions: as a field of consciousness it is not "only" a subjectivity but always already an intersubjectivity. Furthermore, the description of this field is incomplete if only analyzed in a static register. The static description turns out merely to grasp the uppermost stratum within a universe of genetic development. ${ }^{55}$ Phenomenology in this full sense as a theory of world constitution accounts for how transcendental consciousness "forms" the world as product of its experience. Thus, only a full understanding of this consciousness can give the philosopher an equally full concept of the world as life-world. Since transcendental consciousness as world constituting and the life-world as the product of constitution are correlates, thematizing either of them yields a way into phenomenology. Hence, the way via psychology and that via the life-world complement each other. Whether I take my point of departure from mundane consciousness and reduce to its transcendental "counterpart," or if I inquire back from the pre-given life-world to its constituting achievements, I arrive at transcendental (inter-)subjectivity as the "absolute being" that constitutes the world. ${ }^{56}$

This means, if inquiring back into transcendental consciousness reveals the world as what it truly is-a product of the transcendental constitution-then only transcendental phenomenology can render a real understanding of the world as a life-world. In other words, as long as the world is not framed within this correlation, it has not been fully understood. This is also a critique of the positive sciences. It is not the case that they have relinquished their ideal to account for the essence of the world, as much as they have pursued a wrong path and have become blind to the true being of the world insofar as they have abstracted from it and have forgotten its basic character, as a world of everyday life. This is one of the main themes in the 18 Luft 
Crisis, where Husserl tries to give a diagnosis of his time and to show how transcendental phenomenology can help solve this crisis. This "missionary" motif in Husserl's philosophy goes back to the Kaizo-Articles from 1922, in which he calls for a "renewal" of the European spirit. ${ }^{57}$ When some15 years later he diagnoses a "crisis" in modern European culture, he reverts to the same topic. In both cases, Husserl proposes: the world must be saved through rigorous science, this science ultimately beingphenomenology. ${ }^{58}$

What does the crisis of modern European science consist in? Science has departed from the life-world in modernity by its method of mathematization. This process is an abstraction that has converted the world into a mathematical universe. ${ }^{59}$ Two results, again correlative, follow: First, science abstracts from the "real" world and lives in its own world of formulae. It has "forgotten" the life-world. ${ }^{60}$ As a consequence, it loses sight of the original life-world from which it has emerged and continues to emerge. In this process, science not only loses sight of the lifeworld but it replaces it with the scientific world. The life-world has become covered up by a scientific view of this world that does not see the world as what it is in its original sense: a world of prescientific, pre-philosophical life. However, is not the scientific form of life also a form of life, and a very special one? In what sense can the life-world, accordingly, be pre-scientific? Whence this critique of science?

There can be no doubt about Husserl's undiminished high regard for science. One must never understand his call back to the life-world as breaking with the ideal of a "scientific" mastery of the world. That would be a crass misreading of Husserl's famous quote of the dream of rigorous science "ending." ${ }^{11}$ Indeed, the phenomenological approach does thematize the world as a life-world and is conceived as a counter-balance to the positive sciences, but its goal is also, thereby, to bring the sciences back on track. Thus, phenomenology does in no way devalue the achievements of the positive sciences, but wants to embed them in an allembracing scientific endeavor that should remain "in touch" with the life-world from which it has sprung. What, then, does Husserl mean by life-world? ${ }^{62}$ The world of science is opposed to the pre-scientific world. The life-world is hence the world of the pre-scientific attitude; indeed, it is nothing but the world the natural attitude has as its correlate. It is the subjective-relative world of

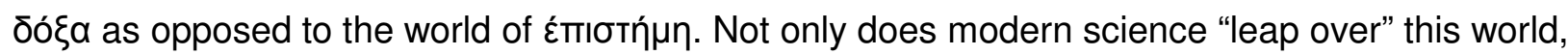
it has been never precisely in its pre-scientific character the theme of a scientific endeavor, because relativity (to the subject, in this case) was its decided terminus a quo; the terminus ad quem was objective truth (and not the "subjective" truth "of the market place"). However, the pre-scientific life-world is the basis of all human actions, natural or scientific. Hence, it is the task 19 Luft 
of phenomenological reflection, first of all, to thematize this life-world, that is, to re-cover it by uncovering the abstractive strata that have become laid over it. Husserl calls for a "reduction to the life-world" in the specific sense of an initial "opening up," because the life-world has been "forgotten" by modern man in striving for a scientific world domination. Strictly speaking, one cannot call this forgetfulness, since it never was thematized in the first place. It has the character of a "primal doxa." Not thematizing this as a foundation even for the sciences, means leaving the latter dangling in open space.

How is this "life-world reduction" executed? Paradoxically, one must carry it out as a scientific endeavor aiming at a universal "ontology of the life-world" (cf. Crisis, §51). As such, it seems it should be carried out in the natural attitude. From the higher, transcendental standpoint, however, the natural attitude has been understood as a "lower"(naïve) form of the former and can only "artificially" be restituted. This could be seen as contradicting Husserl's own intentions in that he seems to rescind the reduction. However, one has to insist that it is a reduction that allows us to see the life-world as such ("stripped" of idealizations). This "life-world reduction" reduces to the world before any idealizations and reveals the sphere of basic life as the fundamental "presupposition"63 of any activity. ${ }^{64}$

An ontology of the life-world has been perhaps one of the most intriguing ideas in the late Husserl. What this ontology consists of and how it is to be carried out shall not be discussed here. However, the very conception of this discipline is important in the present context, because it also yields a way into the transcendental once we realize that the life-world is a "product" of constitution. Indeed, this concrete world of the natural attitude cannot come into view without practicing a universal epoché. One needs the reduction to uncover the sphere of transcendental subjectivity that constitutes this world as the world of the natural attitude, from which any activity takes its stand. Only by understanding the transcendental as constituting can we have access to the world in its base-function, i.e., as pre-philosophical life-world. The reduction must even go beyond the philosophical standpoint, and the phenomenologist has to make her way back into the natural attitude, without, however, forgetting its transcendental "origin." Husserl called this reverse movement "enworlding."65

Only through a universal epoché from the life-world can we attain a full appreciation of the correlation between world and transcendental subjectivity. As Kern puts it: "only the ontological way hence grasps subjectivity really as transcendental."66 Accordingly, only a thematization of the life-world attains a view of the world in its universal dimensions. After all, the world of the scientist is also a "world," despite resting on its un-thematic basis, the life-world. 20 Luft 
The world is thus a universal foundation. Since transcendental subjectivity and life-world are correlates in the framework of constitution, gaining a full grasp of either one includes the possibility of understanding the other; one cannot go without the other. Only from the standpoint of an ontology of the life-world can one practice the transcendental reduction. Likewise, only through a full analysis of transcendental subjectivity in its broadest dimensions can we understand the world as the product of constitution and thus as what it ultimately is: a historic world of life with its genesis, history and a ground on which historic "subjectivities" have developed and can ever develop. Only from this perspective can phenomenology ultimately thematize the transcendental problem of history. Indeed, Husserl insists that the reduction is in no way an impoverishment or a "reducing" of the world to some singular transcendental ego. In fact, the reduction opens up a view on the world by transcending the naivete of the natural attitude towards a universal standpoint. What has sometimes been understood as a "disengagement" with the world turns out to be precisely the way to fully come to understand it. ${ }^{67}$

Furthermore, the discovery of the genetic dimension of world constitution reveals the lifeworld to be not only historical but also, in its historicity, to have "laws of genesis." Tracing back the history of the life-world in its decisive developmental steps-its primal institutings_-reveals these as developments on the way to transcendental phenomenology itself. The sketch of phenomenological "archeology" Husserl performs in the first part of the Crisis in going back to the first rudimentary forms of mathematization in ancient Greece is a reconstruction of how science and philosophy have come about in a certain historical situation. It is a reconstruction of how science arose from the pre-philosophical life-world through a radically new idea, the mathematization of nature. But there is also a "progressive" side to this historical consideration. Husserl's reconstruction of the history of philosophy is also an effort to trace these "primal institutings" as coming ever closer to the discovery of transcendental subjectivity until it-in this very "Hegelian"-reaches its decisive breakthrough in phenomenology. However, neither history nor philosophy come to an end; rather, they should proceed from here-this was Husserl's hope-in a new and transcendentally enlightened style. Thus, by interpreting history teleologically as a critical history of ideas, ${ }^{68}$ it can be under-stood as eclipsing in the reduction and from here as the way into a transcendental reconstruction of the historic life-world.

To sum up, I have attempted to systematically present the three principal ways into phenomenology. Although Husserl never gave a systematic account of these ways, he was, at least at the end of his life, convinced that there was an underlying systematics. There is

21 Luft 
ultimately but one way, which may have its different procedures: the way through the life-world. In a self-critical note, in one of his last manuscripts from 1937, he writes:

I have drafted different introductions into transcendental-phenomenological philosophy.... We shall see that this life-world is nothing but the historical world. From here, it becomes conceivable that a complete systematic introduction into phenomenology begins and is to be carried through as a universal historical problem. If one introduces the epoché without the historic framing, then the problem of the life-world, i.e. of universal history, remains unsolved. The introduction in Ideas [the Cartesian way, sc.] does in fact retain its right, but I now consider the historical way to be more principal and systematic. ${ }^{69}$

\section{Conclusion and Critique: The Reduction Between Transcendental Ego and Life-World}

In various ways Husserl tried to come to terms with what he intended by the reduction. His sometimes emphatic or ceremonious formulations show that he has more in mind than just solving a specific epistemological problem. Rather, the epistemological problem in its full dimensions is of such importance that solving it is comparable to a full "conversion of humankind." However literally these characterizations are to be understood, Husserl emphasizes that he considers the reduction his greatest discovery; he is convinced that it is also the most difficult part of his philosophy. "The reduction" is much more than a purely

methodological device. ${ }^{70}$ At times it becomes a synonym for his entire philosophy. Let us look at the consequences to which this leads.

The discussion of the ways into the reduction has shown that there are two focal points the reduction leads to: the life-world as a constitutive product of the full scope of the transcendental, on the one hand, and, on the other, the transcendental Ego that, discovered by the unparticipating observer, is the basis for any apodictic evidence upon which to build the edifice of science. What are Husserl's intentions in focusing on these two phenomena?

Let us start with the Ego of the phenomenologist. Establishing this observer vis-à-vis transcendental life in the process of constituting the world puts the philosopher in the position of accounting for this transcendental life, which he "partakes" of. This life is, in the last instance, nothing other than "my own." Accounting for it is more than an epistemological task. Since the phenomenological scientist has to legitimate her actions, she has to give account of them responsibly and ultimately for herself. Accounting for one's own deepest "self" is more than just performing another scientific "job"; it is a task of the highest responsibility possible. The "dignity" of the philosopher's activity stems from his duty to act responsibly as a researcher. "Acting rightfully" in doing philosophy is so much an ethical issue that one cannot conceive of

22 Luft 
philosophy as being only a "job." It is rather a "vocation." In this Husserl alludes to the German Beruf (job) as derived from Berufung (vocation). ${ }^{71}$ Being a "good philosopher" becomes an ethical ideal. Contrary to the view that the epoché enacts a "disengagement" with the world, the position of the phenomenological observer is precisely a radical giving an account of this life. This is possible because the "unparticipating" view first makes a universal "overview" possible. This is not to say that everyone ought to become a philosopher. However, becoming one means not only achieving the highest dignity humanly possible but also living humanness, which consists in rationality, to the fullest. Becoming a philosopher as the one who has performed the reduction and discovered absolute life "within" him- or herself, means fulfilling a "self-forming of the ego through absolute reflection to the absolutely genuine human." ${ }^{\text {"72 }}$ it is an ideal task of justifying all of one's actions and taking responsibility for them. This lies within the teleology of human (rational) faculties. If practical rationality is a question of freedom, then the philosopher's actions in her "phenomenologizing" activity are a genuine pursuit of freedom. Moreover, the philosopher is even grander in this pursuit of freedom since she has become aware of this freedom as a full instantiation of rationality discovered in leaving the boundaries of the natural attitude. It is a freedom understood, rather than "blindly" acted out. ${ }^{73}$

Yet, the transcendental life I discover within myself is more than my own life. The reduction yields the insight that transcendental achievements never belong only to me; the world is never a product of my activity alone but of a transcendental intersubjectivity. Individual subjectivity becomes formed only in terms of others, the ones before me and after me, the ones I have never encountered and never will encounter, etc. All of these have "contributed" to the world as it is. Thus, the reduction gives access to transcendental life as such, and hence breaks the spell of solipsism. In and through transcendental intersubjectivity we are bound together in one "spiritual" totality. Thus, Husserl calls the philosophers the "functionaries of mankind." They can assume this function insofar as taking over responsibility for myself directly leads to all the others as united in the totality of "monads." The philosopher has a double task. On the one hand, he interprets the life of humankind in an "absolute" view. On the other, the philosopher in

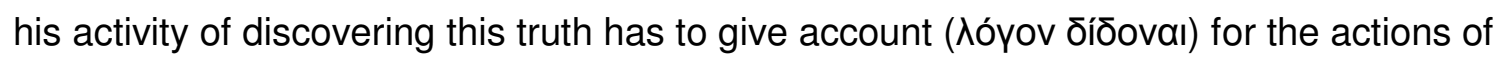
mankind in their relative ways of life and in the multitude of (special) worlds. Giving a description of this life in this world is the first step of judging human actions. Thus, Husserl states programmatically, "phenomenological explication does nothing but explicate the sense this world has for us all, prior to any philosophizing, and obviously gets solely from our experiencea sense which philosophy can uncover but never alter."74

23 Luft 
Thus, the philosopher's role is that of calling mankind back to its preconceived, teleological path. This is the role that the philosopher and citizen Husserl assumed in the Crisis at a time in which not only science had deviated from its designated path but a whole nation had gone astray, blinded by a frenzy of nationalism and racism. Husserl's calling for a reform of science in the light of the political upheaval in Nazi Germany might seem utterly naïve to us. However, one must bear in mind what science meant in the whole of human culture to Husserl: Scientific and ultimately philosophical activity are the highest realizations of human life as such. In this "emphatic" sense the philosopher's role might well be described, with Nietzsche, as a "doctor of culture." Indeed, a "crisis" can also be understood in medical terms as the crest of a sickness. Thus, the philosopher cannot directly intervene in the course of history-the sense of the world is one that can "never" be altered. Rather, one can only react to a disease that has already taken its course; that is, the philosopher has the duty to point out where and why, from which motives, this deviation from the "good" path has occurred and show possible ways out of the crisis.

However, despite the emphasis on the philosopher's role as standing in lieu of humanity, Husserl insists on the "uniqueness" and "personalindeclinability"75 of the philosophizing ego. Despite Husserl's emphasis upon intersubjectivity, he holds that the agent can never be "reduced" to an irrelevant, contingent mode within an inter-monadic totality:

The 'l' that I attain in the epoché....is actually called 'l' only by equivocationthough it is an essential equivocation since, when I name it in reflection, I can say nothing other than: it is I who practice the epoché, I who interrogate, as phenomenon, the world which is now valid for me according to its being and being-such, with all its human beings, of whom I am so fully conscious; it is I who stand above all natural existence that has meaning for me, who am the ego-pole of this transcendental life, in which, at first, the world has meaning for me purely as world; it is I who, taken in full concreteness, encompass all that. ${ }^{76}$

Thus, Husserl's philosophy remains a critical transcendental philosophy that can never do without an absolute ego as foundation and starting point of all reflection. It is precisely this "Cartesianistic" motif that Husserl never gives up, because it is connected to the idea that there is ultimately an apodictic foundation, an "Archimedean point" that provides a final foundation in the evidence of the ego. The consequence of the reduction pursued thus far leads to a partial validation of the "Cartesian" Husserl. It is from this approach only that he can interpret the role of the philosopher in the framework of cultural activity of mankind. In order to secure this cultural 
implication and to enable the philosopher to be more than a citizen of an ivory tower, Husserl "needs" Cartesianism.

However, on the other side of the balances, there is the issue of the life-world, which becomes increasingly important to the later Husserl. Some scholars, most forcefully Husserl's own former assistant Landgrebe, have interpreted Husserl's turn of attention to the pre-scientific world as a "departure from Cartesianism,"77 as Landgrebe famously phrases it. His argument is that Husserl realized that he could not lay an apodictic foundation in the Ego. Therefore, he (more or less consciously) abandoned this project and instead turned to the life-world as the actual working field of phenomenology. Performing an "ontology of the life-world" is the true task for phenomenology. In order to do this, one does not need a Cartesian reduction to a transcendental consciousness. Hence, the departure has already occurred behind Husserl's back, the moment he turned to the life-world as his primary field of interest. This reading of Husserl's late philosophy has been very dominant in the first decades after Husserl's death and has clearly been influenced by Heidegger, more precisely by the notion that Husserl himself was (subconsciously) influenced by Heidegger's hermeneutics of facticity. This is evidenced, supposedly, by Husserl's unfinished sketch of a life-world ontology. The fact that this ontology was never worked out in detail and only hinted at in the Crisis was taken as an implicit proof that the problem of the life-world was merely an "afterthought," a glimpse of something radically new that Husserl was not able to give account of ultimately. ${ }^{78}$ It was an idea hinted at rather than clearly seen in view of its consequences, namely, that it would lead to an abandoning of his transcendental project.

However, in the past three decades a good deal of manuscript material from Husserl's Nachlass has been published showing that a "theory of world apperception"79 is in fact not only worked out in great detail; indeed, Husserl had been working on a life-world interpretation already since the early 1920s. Since this material has become known, the "departure"-thesis has become highly problematic, and there is consensus among scholars that Husserl ultimately was not able to "achieve" this last step. ${ }^{80}$ More importantly, it could never have been his intention to leave Cartesianism behind. But how can both tendencies be reconciled? Although Landgrebe's assessment of Husserl's late thought is clearly incorrect, and if one, furthermore, "substracts" the Heidegger-inspired overtones of this interpretation, did he perhaps see something that is not altogether wrong?

As has been shown, transcendental and life-worldly, "ontological" analysis complement each other to Husserl. Therefore, the reduction is needed in order to access this life-world, since 25 Luft 
in all "normal" pursuit of life it is un-thematic and remains all the more un-thematized in modern science. That is, by science's abstracting from the life-world, it is nevertheless bound to it unknowingly. Thematizing the life-world, as that which always remains un-thematized in the natural attitude, means already having left the natural attitude. Nevertheless, this does not mean doing away with it. To the contrary, it remains the basic form of life (the philosopher remains a citizen, a father, a mother etc.). From the transcendental standpoint one understands the natural attitude as a "lower" stance, or which says the same, the natural attitude is already transcendental, yet without knowing it. The natural attitude is "implicated" in the transcendental perspective. $^{81}$

For an ontology of the life-world, this entails that Husserl's "resti-tuting" ${ }^{\text {"2 }}$ of the natural attitude in order to attain a standpoint to analyze it cannot mean that we, the analyzing philosophers, are to "forget" the perspective gained in the reduction. Going back into the old attitude, resuscitating the old naiveté, is impossible, as Husserl points out. Rather, this step back must be understood as a quasi-imaginary move: I pretend to go back into the "old" attitude and from there description of life-world can proceed in analyzing what life in the natural attitude was like before I became aware of it. We can understand "restitution" in this context as "reconstruction" of something that has been "un-built" in transcendental analysis. ${ }^{83}$ This is why performing the reduction rightly understood does not stand in contradiction with the task of a life-world ontology. Tersely put: Without the reduction, we would never gain an uninhibited view of the life-world

Yet, although this ontology is "enabled" through the transcendental turn, it is also true that this discipline soon takes on its own character. Describing the world from its most primitive elements, through first formations of communal life to higher-order personalities and ending up finally in cultures, home-worlds, alien-worlds, etc. is a gigantic field of research. The rich methodological instruments Husserl has forged in his development of a genetic phenomenology provide the tools needed to pursue this task. In fact, one can say, this method takes on the character of a hermeneutics of the life-world, as it is the world given to experiencing subjects. It is a description of how the world we live in has come to be and how it functions. The term "hermeneutics"-which Husserl uses in a similar context-is designated to mean precisely this. It is rather a descriptive than a normative discipline. Where Husserl attempts such descriptions - for example, in analyses of Greek culture and philosophy—the "genetic" is oftentimes indistinguishable from factual-historical analyses. ${ }^{84}$ It is thus not surprising that quasiphilosophical disciplines such as sociology, political theory, history, and pedagogy have taken

26 Luft 
up Husserl's ideas on the life-world. Furthermore, it cannot be accidental that the term life-world has become almost a household name that nowadays has little to do with its origin. The very "mundaneity" of the problem of the world of life suggests its remoteness from transcendental questions.

Thus, the interpretation presented here attempts to overcome the common assertion that there is a "contradiction" between Husserl's Cartesian position and his account of the life-world. I have tried to show that a philosophical thematization of the life-world is not possible without a transcendental question as to its origin in (inter-)subjectivity. In Husserl's eyes, both agendas are correlative. At the same time, I would like to insist that Husserl's Cartesian account of the subject and his life-world ontology present two distinct and in this sense, separate programs. They are projects Husserl pursues with different aims: Whereas the "Cartesian Husserl" pursues a path of scientific grounding and foundationalism, the "life-world Husserl" is interested in what can been called a hermeneutics of the world of everyday life. Both projects are set squarely against each other, not in the sense that they contradict or cancel each other out, but in that they pursue two different agendas. They are located on two different "maps." One can pursue one while completely neglecting the other. It is possible to pursue a "theory" of the life-world without at all being interested in transcendental ("constitutional") problems. Likewise, one can immerse oneself in transcendental matters in the tradition of Kant and German Idealism, and fruitfully utilize Husserl's contributions to transcendental theories. ${ }^{85}$ In the wake of fundamental criticisms of reason and rationality especially in the second half of the twentieth century, it is understandable why this path has been of less interest than the former. This, however, cannot be a reason to discard this aspect of Husserl. In fact, neglecting the Cartesian Husserl leads to fundamental misunderstandings. These disregard the fact that Husserl never came close to considering transcendental phenomenology and the idea(l) of rigorous science a dream, let alone a dream that could come to an end. ${ }^{86}$

This leads, however, to the concluding critical observation. Namely, Husserl failed to combine these two major aspects of his philosophical endeavor. There is neither just the "Cartesian" nor the "life-world Husserl." There is of systematic necessity both. However, there can-not be a systematic principle uniting both, since formulating such a principle would make the problematic step of considering one of the two projects as absolute. Favoring one would result in devaluing the other. It is inconceivable how foundationalist questions following the Cartesian paradigm would fit into a life-world ontology, precisely because this ontology is based on "the transcendental" as necessarily an inter-subjectivity. Likewise, it is not clear why such a

27 Luft 
life-world ontology would "need" foundationalist clarifications other than clarifying the role of the philosophizing agent, who is but a minimal focal point of experience of the life-world.

Metaphorically speaking, on the "map" of the life-world, the Cartesian Ego is an infinitesimally small point. On the Cartesian "map," the problem of the life-world comes very late, so that it lies almost on another "continent." This is the consequence of the Janus head of the phenomenological reduction. A sign of Husserl's keen philosophical view is that he had looked in both directions, "back-wards" into the depths of transcendental life and "forward" into the world. But, as profound as Husserl's instinct was, this view is either one-eyed or squinting.

The reduction thus has the double meaning of calling humanity to its utmost possibilities, to the "true" and "genuine" rational human being within one's self, on the one hand. On the other, its task is to convey an all-embracing understanding of the world we live in, including ourselves as dwellers in this world of interests and distinct activities. The conflict of absolute humanity and relative life pursuit however remains: we are left with the paradox of human subjectivity, the resolving of which nobody else can decide but history itself in which reason unfolds teleologically-or where it can always disperse and even become lost. Performing the phenomenological reduction, to Husserl, is nothing but the constant attempt to "come to reason," although there might be factual hindrances on the way to this ideal-a way which necessarily leads through the life-world.

With the reduction, Husserl has touched upon the fundamental issue of freedom, the freedom to be oneself, or which is to say the same, the freedom to open oneself to reason as the true meaning of humanity. The possibility of performing the phenomenological reduction would thus be identical with the extent to which freedom is possible. ${ }^{87}$ The critical assertions mentioned notwithstanding, the reduction is Husserl's contribution to philosophy in the tradition of the enlightenment that does not uncritically accept rationality as a given, but wants to conceive of it within a transcendental and intersubjective account of subjectivity. There might be no way to unify the issues of life-world and Cartesianism, but there might also be no other way to go than into these two, opposite directions. ${ }^{88}$

\section{Notes}

1. Whereas the first generations of Husserl scholars (e.g., E. Fink, R. Boehm, L. Landgrebe, I. Kern) dealt extensively with the problem of the reduction, lately, especially in the French phenomenological scene, the reduction has again been a dominant theme, cf. the works by M. Henry and J.-L. Marion. For a good overview of these newer tendencies cf. 
R. Bernet, "La réduction phénoménologique et la double vie du sujet," in La Vie du Sujet. Recherches sur l'Interpretation de Husserl Dans la Phénoménologie (Paris:Presses Universitaires de France, 1994), 5-36.

2. Cf. "Der Zukunft bin ich sicher" [I am certain of the future], letter to his friend G. Albrecht, December 29, 1930,Briefwechsel, ed. K. Schuhmann with E. Schuhmann,vol. 3 of Husserliana Dokumente(Dordrecht: Kluwer Academic Publishers, 1994),3/9:75f. In the following, Husserl's Collected Works, Husserliana: Gesammelte Werke(DenHaag:M. Nijhoff, 1950ff.), shall be abbreviated as Hua, followed by volume and page numbers.

Hua VI: DieKrisis der Europäischen Wissenschaften und die Transzendentale Phänomenologie,ed. K. Schuhmann (Den Haag: M. Nijhoff, 1976); translated by David Carr underthe title The Crisis of European Sciences and Transcendental Phenomenology(Evanston: Northwestern University Press, 1970); hereafter cited as Krisis and Crisis,quoting theGerman and English pagination respectively.

Hua III/l:Ideen zu einer reinen Phänomenologie und Phänomenologischen Philosophie, vol.1: Allgemeine Einführung in die Reine Phänomenologie, ed. W. Biemel (Den Haag: M. Nijhoff,1950); hereafter cited as Ideen I; translated by F. Kersten under the title Ideas Pertaining to a Pure Phenomenology and Phenomenological Philosophy, First Book: General Introduction to a Pure Phenomenology(The Hague: M. Nijhoff, 1982); hereafter cited as Ideas $I$.

3. The metaphor of a religious conversion is the image Husserl uses in the Crisis, cf. Krisis, 140; after Crisis, 141.

4. Cf. Hua VIII: 19.

5. On a supposed "metaphysical neutrality" already in Husserl's early works, cf. D. Zahavi, "Metaphysical Neutrality in Logical Investigations," in One Hundred Years of Phenomenology. Husserl's "Logical Investigations" Revisited, ed. D. Zahavi and F. Stjernfelt.Phaenomenologica 164 (Dordrecht: Kluwer, 2002), 93-108.

6.I. Kern, "Die Drei Wege zur Transzendental-Phänomenologischen Reduktion," inTijdschrift voor Filosofie24 (1962): 303-49. I shall refer to this article subsequently.

7. Cf. Crisis, appendix text no. XVII, pp. 459ff., where Husserl speaks of "Sonderwahrheiten"(special, particular truths).

8. Cf. Hua XI: $23 f$.

9. This aspect in Husserl's account of the life-world was taken up in Gadamer's hermeneutics. Cf. his discussion of Husserl in Truth and Method, part II, §I.3. A, 
"Theconcept of life in Husserl and Count Yorck" (Truth and Method,trans. J. Weinsheimer and D.G. Marshall, 2nd rev. ed. [New York: Crossroad, 1989], 242ff.).

10.Cf. Hua VIII: $98 f f$.

11. Because the conception of life is considered here from the perspective of the natural attitude, the topics of passivity and self-affectivity are not germane to this discussion. For a reconstruction of this pre-affective life, cf. D. Zahavi, "The Fracture in Self-Awareness," in Self-Awareness, Temporality, and Alterity, ed. D. Zahavi. Contributionsto Phenomenology 34 (Dordrecht: Kluwer, 1998), 21-40, as well as R. Kühn, Husserls Begriffder Passivität. Zur Kritik der passiven Synthesis in der Genetischen Phänomenologie.Texte und Kontexte 6 (Freiburg: K. Alber, 1998).

12. Cf. Hua. XV: 196-218, Text no. 14 (+ appendix XI); cf. also the critical interpretation by K. Held, "Heimwelt, Fremdwelt, die eine Welt," Phänomenologische Forschungen 24/25 (1991): 305-37.

13. Cf. Krisis, 161f., §46, and ibid., 169 n; Crisis, 159f., ibid., 166 n.

14.Cf. Husserl's first account of the natural attitude in Ideas I, §27ff., as well as his later, more elaborate analyses in the manuscript material, published in Hua XV, as well as in Crisis, §§34-37. Cf. also his especially penetrating accounts of attitudes in his research manuscripts especially from the fall of 1926 (Hua XXXIV: 3-109).

15. Cf. Krisis, 158f., §44; Crisis, $155 f f$.

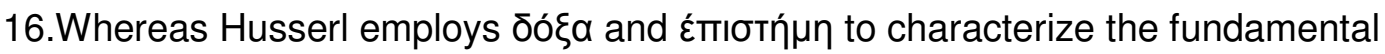
nature of this distinction —and hence the radically new nature of phenomenology - he speaks of "Neustiftungen" (new/novel institutings) over against the original primal institutings in early Greek thought; cf. his late text on "Teleology in the History of Philosophy," in Hua XXIX: 362-420, Text no. 32.

17. He also commends the British Empiricists in their development of a scientific psychology. However, as for the development of transcendental philosophy, the decisive figures of modern philosophy are the ones mentioned above. Cf. D. Cairns, Conversations with Husserl and Fink. Phaenomenologica 66 (Den Haag: M. Nijhoff, 1976), 104; hereafter cited as Conversations.

18. Apart from the "classical" schema first established by Kern, Fink mentioned at least one more way, that via the sciences. Be that as it may, Husserl did not have such a clear vision of the different ways, one of the reasons being that he developed them over the course of more than twenty years and that they often intermingle. For example, the way via

30 Luft 
the life-world (the one presented in the Crisis) is also in a sense that via history, insofar as the life-world should be conceived rightfully as "historical life-world."

19. Cf. Hua XXIX: 425f. This passage will be discussed subsequently.

20. Cf. Cairns, Conversations, 11f., footnote 18, where this example is mentioned.

21.Cf. Held, "Husserls Rückgang auf das phainómenon und die geschichtliche Stellung der Phänomenologie," Phänomenologische Forschung 10 (1980): 89-145.

22. Cf. Hua VII: 159.

23. Cf. Ideen I, 52, §30; Ideas I, 56. Cf. also Hua VIII:44-50, where Husserl formulates the "content" of the General Thesis as "the world is" (Die Welt ist).

24. Ideen I, 53, §30; after Ideas I, 57.

25. Ideen I, 54; after Ideas I, 58. Cf. also the recent study by M. Brainard, Belief and its Neutralization. Husserl's System of Phenomenology in Ideas I (Albany, NY: State University of New York Press, 2002), part II, chaps. 3 \& 4. This concept of freedom influenced Sartre's concept of "radical freedom." Cf. Being and Nothingness, trans. by H.E. Barnes (New York: Philosophical Library, 1956), 315ff.

26. In his early years, Husserl was influenced by Schopenhauer's philosophy, cf. K. Schuhmann, Husserl-Chronik (Den Haag: M. Nijhoff, 1977), 9, 34, 51. Although there is no mention of Schopenhauer in Husserl's later years, it rings a striking bell when Husserl characterizes the natural attitude (the "world of representation," in Schopenhauer's words) as an attitude of "willing" which affirms being, and the epoché as a bracketing, suspending and "letting go" of this basic life impulse.

27. Ideen I, 54; after Ideas I, 58.

28. Ibid.

29. Hua I: 63; after Cartesian Meditation: An Introduction to Phenomenology, trans. D. Cairns (The Hague: M. Nijhoff, 1960), 24; published as Hua I: Cartesianische Meditationen und Pariser Vorträge, ed. S. Strasser (Den Haag: M. Nijhoff, 1963).

30. This anticipates the problem of the relationship between the "mundane" and the transcendental ego. This problem, which was also of particular interest to Husserl's last assistant Eugen Fink, cannot be discussed here. Cf., however, S. Luft, "Phänomenologieder Phänomenologie":Systematik und Methodologie der Phänomenologie in der Auseinandersetzungzwischen Husserl und Fink. Phaenomenologica 166 (Dordrecht: Kluwer, 2002), esp. chap. 4. 
31. This tendency finds its most extreme execution in the lecture course from 1922/23, Einleitung in die Philosophie, Hua. XXXV, where Husserl performs the "apodictic reduction" in order to gain an absolute foundation within the sphere of transcendental life. In this attempt of an ultimate foundationalism (Letztbegründung), he was mainly influenced by the neo-Kantians.

32.Cf. the manuscript on the "meaning of the apodicticity of the I-am" from 1934 (Hua XXXIV: 467ff.), where Husserl emphasizes the importance of making the apodictic "I-am" the foundation of philosophical thought, although with the most significant addition that this "apodicticity" includes the world as a cogitatum (cf.ibid., 469).

33.This "Platonistic" interpretation was widely held by some of Husserl's contemporaries after the publication of Ideas I. Cf., for example, Natorp's review of Ideas from 1917/18, published in Logos(reprinted in Husserl, ed. H. Noack [Darmstadt:Wissenschaftliche Buchgesellschaft, 1973], 36-60), or more strongly even Heideggerin his Marburg lecture course from 1925/26; cf. M. Heidegger, Logik. Die Fragenach der Wahrheit, ed. W. Biemel, vol. 21 of Gesamtausgabe (Frankfurt a.M.: Klostermann,1976), 31-125.

34. Cf. also the London Lectures from 1922, where he speaks of phenomenology as the "mathesis universalissima." Cf. Hua. XXXV: 305.

35. In this he is consistent with the first presentation of the reduction in the 1907 lectures on the Idea of Phenomenology; cf. Hua. II: $4 \mathrm{f}$.

36. Ideen I, 51; after Ideas I, 44f.

37. Ideen I, 77; after Ideas I, 90. It should be mentioned, however, that in Cartesian Meditations, Husserl distinguishes adequate and apodictic evidence. Adequate evidence is not eo ipso apodictic (the evidence of transcendent objects is neither adequate nor apodictic, that of immanent objects adequate but not necessarily apodictic), although both yield "evidences." This is a reflex of the broadening of the concept of phenomenological evidence as Husserl broadens the "field" of subjectivity. Cf.Hua: I, §6f.

38. For an account of Husserl's mature theory of lived-present, cf. K. Held, Lebendige Gegenwart. Die Frage nach der Seinsweise des transzendentalen Ich bei Edmund Husserl, entwickeltam Leitfaden der Zeitproblematik. Phaenomenologica 23 (Den Haag: M. Nijhoff, 1966).

39. Hua XXXV: 93f.: "Das scheinbar armselige ego cogito hat uns ein endloses Gebiet vielverschlungener Phänomene eröffnet, einen phänomenologischen Urwald 32 Luft 
sozusagen....[N]ur als transzendentales Ich durfte er [the beginning philosopher] sich setzen und nur sein absolutes Leben mit cogito und cogitatum ist ihm übrig. Unendlich vieles liegt aber, scheint es, darin."

40. Cf. Cartesian Meditations, Hua I: $70 \mathrm{ff}$.

41. This effort can best be seen in the lecture course from 1925, Phänomenologische Psychologie, Hua IX.

42. On the topic of "Gemeingeist" cf. Hua XIV: 165-232.

43. One should not forget that "transcendental questions" also involve questions regarding truth claims and reason, concepts that a psychology as a science of consciousness does not (have to) deal with. Cf. Hua XXXV: 301: "Es ist ein Widersinn, aus der Psychologie irgend etwas über das Wesen der Erkenntnis, über das Wesen des Ich, des Bewusstseins und seiner Wesensmöglichkeiten und -notwendigkeiten intentionaler Konstitution von Gegenständlichkeiten lernen zu wollen und somit von ihr etwas lernen zu wollen über die Vernunft, nicht als eine empirische Charaktereigenschaft, sondern als einen Titel für Wesensstrukturen der Erkenntnisgeltung, in der sich erkenntnismäßig Abzielung und Erzielung abspielen, in der eine teleologisch geordnete Sinngebung unter dem Telos 'wahres Sein' erfolgen und jede Gegenstandsregion ihre mögliche Selbstgegebenheit, ihre gültige Anerkennung als seiende und ihre logische Bestimmung erfahren kann."

44. This notion is introduced in the beginning of the '20s. Already in the lecture course from 1923/24 (Erste Philosophie), the term seems well established and has its distinct meaning; cf. Hua VIII: 126-31.

45. Hua VIII: 89 (my translation).

46. For the discussion of patent and latent Ego, cf. Hua VIII: 90-92. For a more detailed account of the splitting of the ego, cf. also Hua XXXIV: 41ff., Text no. 2.

47. Krisis, 179; Crisis, 176, where Carr translates this term as "infatuation" (without making a reference to the pun).

48. Krisis, 182ff.; Crisis, $178 \mathrm{ff}$. On the paradox of subjectivity, cf. D. Carr, The Paradox of Subjectivity. The Self in the Transcendental Tradition (New York: Oxford University Press, 1999). In this book, Carr sets out to place this paradoxical character of subjectivity in a broader historical context-most importantly Kant-and argues that the "transcendental tradition" offers a critique of subjectivity that is "much more subtle and devastating...than the one put forward by Heidegger" (ibid., 140). 
49. Krisis, 203; after Crisis, 207. Cf. also Hua. XXXIV: 125ff., Text no. 7. On the alleged "parallelism" of psychology and phenomenology, cf. also S. Luft, "Über einige Grundprobleme in Husserls späten Texten über Reduktion," in SubjektivitätVerantwortung-Wahrheit. Neue Aspeke der Phänomenologie Edmund Husserls, ed. D. Carr and C. Lotz. New Studies in Phenomenology, vol. 1(Frankfurt a.M.: P. Lang, 2002), 127-48, esp. 135-39.

50. Cf. Hua. VII: 9ff.

51. For an account of responsibility in Husserl's philosophy, cf. K. Held, "Evidenz und Verantwortung," in M. Fleischer, ed., Philosophen des 20. Jahrhunderts (Darmstadt:

Wissenschaftliche Buchgesellschaft, 1989), 79-94, and F. Kuster, Wege der Verantwortung. Husserls Phänomenologie als Gang durch die Faktizität. Phaenomenologica 138 (Dordrecht:Kluwer, 1996).

52. This is Husserl's path into phenomenology in the Cartesian (!) Meditations from 1931 (originally published as Méditations Cartésiennes, trans. E. Levinas and G. Peiffer [Paris: A. Colin, 1931]). Cf. esp. Cartesian Meditations, §§3-5.

53. Natorp's work on psychology from 1912, which was closely read by Husserl, bears the title Allgemeine Psychologie nach Kritischer Methode (Tübingen: J. C. B. Mohr, 1912).

54. Cf. I. Kern, "Die Drei Wege zur Transzendental-Phänomenologischen Reduktion," op.cit., here $327 \mathrm{ff}$. Unlike Kern, I differentiate the way via the life-world proper from that via regional ontologies. I consider it as part of the way via the positive sciences and as such I treat it as part of ' $\mathrm{B}$ '.

55. Cf. the text on "static and genetic method" in Hua. XI: 336-45. Cf. also D.Welton, The Other Husserl. The Horizons of Transcendental Philosophy (Bloomington: Indiana University Press, 2000), which deals largely with Husserl's development of a genetic phenomenology.

56. On the question of the "absolute being" of transcendental subjectivity cf. Hua. VIII: 497-506, and Landgrebe's "Meditation über Husserls Wort 'Die Geschichteist das große Faktum des absoluten Seins'," in Faktizität und Individuation(Hamburg: Meiner, 1982), 38-57.

57. Only two of the five Kaizo articles were published in the Japanese journal "The Kaizo" (Japanese for "Renewal"); they have been published as a whole in Hua. XXVII: 3-94. 
On Husserl's "political" philosophy cf. also K. Schuhmann, Husserls Staatsphilosophie (Freiburg: K. Alber, 1988).

58.A certain "missionary" impetus can also already be found in his article "Philosophy as Rigorous Science" (1911); translated by M. Brainard in The New Yearbook for Phenomenology and Phenomenological Philosophy, ed. Burt C. Hopkins and Steven G. Crowell (Seattle: Noesis Press, 2002), 249-95. Already the Logical Investigations make the claim for a radical reform of psychology, and from there the totality of sciences.

59. Cf. the Galilei-paragraph in the Crisis(§9) for a detailed reconstruction of thisprocess.

60. This thesis of science's forgetfulness of the life-world rings familiar with Heidegger's critique of modern philosophy as "leaping over" the problem of the world, although to Heidegger getting back to the world is only possible by doing away with the dualism between subjectivity and objectivity altogether (under the heading of a "destruction of metaphysics"), whereas to Husserl this forgetfulness is a crisis of a logical consequence of scientific progress in modernity.

61. Cf. Krisis, 508; Crisis, 389. Cf. also D. Carr's interpretation of this quote in his translator's introduction, Crisis, p. xxxf. as well as p. xxxi n. 21. Although it has become "old hat" for Husserlians to correct this misreading, it shall be mentioned for the sake of completeness: Husserl's often-quoted phrase in an appendix text of the Crisis, "the dream [of philosophy as rigorous science] is over [ausgeträumf]," does not express his own opinion, but in this he mockingly formulates the position of his critics. Cf. Krisis, 508, Appendix Text no. XXVIII.

62. This answer is but one reading of Husserl's concept of the life-world. Cf. U.Claesges, "Zweideutigkeiten in Husserls Lebenswelt-Begriff," in Perspektiven Transzendentalphänomenologischer Forschung. Für Ludwig Landgrebe zum 70. Geburtstag, ed. U. Claesges and K. Held. Phaenomenologica 49 (Den Haag: M. Nijhoff, 1972), 85-101; as well as R. Boehm, "Husserls drei Thesen über die Lebenswelt," in Lebenswelt und Wissenschaft in der Philosophie Edmund Husserls, ed. E. Ströker (Frankfurt a.M.: Klostermann, 1979), 23-31.

63. Cf. Krisis, 105; Crisis, 103.

64.While it is known that Husserl, in trying to reveal this natural life-world, is influenced by Avenarius' notion of the "natürliche Weltbegriff," it is historically interesting to mention that in a treatment of Avenarius' philosophy, the philosopher Leopold Ziegler, in his 
essay "Ueber einige Begriffe der 'Philosophie der reinen Erfahrung”'[On Some Concepts of 'Philosophy of Pure Experience'], in Logos II (1911/12), Heft 3, pp. 316-49 (in Husserl's library), uses precisely the term "reduction" to characterize the movement necessary to uncover this "world": "[T]he plan of an intentionally ahistorical comportment towards the world is not easily carried through. A brief reflection must teach the philosopher the impossibility to just simply think about the world. For what is the world?...Suddenly a task of its own difficulty arises before the thinker. That is, to lead the 'world' back [zurückführen] to such simplified basic notions, so that it in its totality becomes manageable [handlich] to thought, manageable [handhablich] for human spirit. On this first reduction, which necessarily has to be carried through in the development of any philosophy, depends not only its further conception [Durchbildung], its organization; rather, it remains also guiding [bestimmend] for the relationship and the contradiction between schools and directions, which history enumerates. The simplification, violent as well as unavoidable, of the 'all and everything' to original, complementing notions such as infinite and finite, moving and resting, becoming and being, one and many, temporal and eternal, being-for-itself and being-for-us, conscious and unconscious, body and soul, thinking and being, state of affairs and objectthis simplification shows to the connoisseur [Kenner] a multitude of systematic accounts and historical philosophemes, which in all parts are governed by the reduction of beginnings. Perhaps no thinker other than Avenarius has so much tried to make the effort, as theoretically unsuspiciously as possible, to break reality down into a number of last basic notions" (316f., my translation).

65. On Husserl's (and Fink's) concept of "enworlding" (Verweltlichung), cf. R. Bruzina, "The Enworlding (Verweltlichung) of Transcendental Phenomenological Reflection: A Study of Eugen Fink's ' $6^{\text {th }}$ Cartesian Meditation'," in Husserl Studies 3 (1986): 3-29, as well as the recent study by S. Luft, "Phänomenologie der Phänomenologie,"op.cit., esp. chap.4.

66. Kern, "Die Drei Wege zur Transzendental-Phänomenologischen Reduktion," op.cit., 344 (my translation).

67. It was Merleau-Ponty who clearly saw this "mundanizing" import of the phenomenological reduction, cf. Phénoménologie de la Perception (Paris: Gallimard, 1945), p. I, where he makes a reference to the Vlth Cartesian Meditation.

68. This is the title of the first part of the lecture course on Erste Philosophie, cf. HuaVII. 
69. Hua XXIX: 425f. (my translation).

70. Cf. some of the passages listed in the editor's introduction to Hua XXXIV: XXxxiii.

71. Cf. Hua. XXIX: 353 (my translation): "Is vocation [Berufung] an empty word? Has a philosopher ever...been a 'genuine' philosopher without the demonism of having received such a vocation? Is philosophy to the genuine philosopher as a random so-called lifeoccupation [Lebensberuf], is it for him not rather fate, which for him has decided over being and non-being?"

72. "Selbstgestaltung des Ich durch absolute Reflexion zum absolut echten Menschen"(manuscript A V 5/16b, probably from the 1930s, of the Nachlassin the HusserlArchive, Leuven).

73. Only this kind of reflected freedom can account for one's "good conscience" as opposed to the "intuitively" conscientiously acting person. Thus, only the philosopher can truly have a "good conscience" and her life can come to a "rest" here. Cf. Hua XXXIV: 518, the critical note to p. 40, line 27.

74. Cartesianische Meditationen, 177; after Cartesian Meditations, 151.

75. Krisis, 188; after Crisis, $184 f$.

76. Krisis, 188; after Crisis, 184.

77. Cf. Landgrebe, "Departure from Cartesianism," in L. Landgrebe, The Phenomenology of Edmund Husserl, edited with an introduction by D. Welton (Ithaca: Cornell University Press, 1981), 66-121.

78. Cf. Landgrebe, Faktizität und Individuation, op. cit., p. vii: The shift to the lifeworld is an approach, "von deren Tragweite sich Rechenschaft zu geben inm [Husserl] nicht mehr vergönnt war."

79. This is the title of section A VII of the Nachlass in the Husserl-Archives in Leuven.

80. Cf. K. Held, "Abschied vom Cartesianismus. Die Phänomenologie Edmund Husserls," in Neue Zürcher Zeitung 76 (March 30/31, 1996); in this comprehensive article, Held summarizes this debate lucidly and concludes that Husserl was ultimately not able to overcome "Cartesianism." One can even go further to say that he neither strived to.

81. The topic of "implication" of the natural in the transcendental standpoint is very dominant in Husserl's late texts on the phenomenological reduction. Cf. Hua. XXXIV: 454ff., Text no. 32 (“Die Implikation der Transzendentalen Subjektivität”).

37 Luft 
82. Cf. Krisis, 176.

83. Husserl owes this notion of reconstruction to Natorp, to whom the "reconstructive" method of psychology was the only way to analyze subjectivity. Cf. Natorp's Allgemeine Psychologie nach kritischer Methode,op. cit., which Husserl studied closely. For an account of Natorp's influence on Husserl, cf. I. Kern, Husserl und Kant.

Phaenomenologica 16 (Den Haag: M. Nijhoff, 1964), 321-73, §§29-33.

84. Which has caused Husserl to be charged with "Eurocentrism." This discussion cannot be reiterated here. However, Husserl explicitly does not want to give a factualhistorical account but rather one of "laws of genesis," i.e., an ideal reconstruction. In a late text he even calls this reconstructive reading an "interpretation": "It is an interpretation, i.e., a sort of substruction of facts for which all testimonies are lacking" (Hua. XXIX: 396; my translation, emphasis added).

85. One example of this is to be found in K. Düsing, Selbstbewußtseinsmodelle. Moderne Kritiken und Systematische Entwürfe zur Konkreten Subjektivität(Munich: Fink, 1997); Husserl is one systematic voice in a systematic transcendental theory of selfconsciousness.Cf. 113-16.

86. Cf. here, footnote 61.

87. Cf. H.-L. van Breda: "Seine Freiheit wiederzugewinnen heißt also, sich von der Welt frei machen oder wenigstens ihre autonome Quelle, das transzendentale Ego, wiederfinden. Diese Entdeckung ist bekanntlich nach Husserl nur durch die transzendentale Reduktion möglich" ("Husserl und das Problem der Freiheit," in Husserl,ed. H. Noack, op. cit., 277-81, here 281.

88. I would like to thank Matthias Jung and especially Donn Welton for helpful comments, and Donald R. Moore for help with grammar and style. 